\title{
Protective effect of pre-supplementation with selenium on cadmium-induced oxidative damage to some rat tissues
}

\author{
S. G. MAFULUL* and Z.S.C. OKOYE \\ Department of Biochemistry, Faculty of Medical Sciences, University of Jos, P.M.B. 2084, \\ Jos, Plateau State, Nigeria. \\ *Corresponding author; E-mail: mafsimonsg@yahoo.com; mafululg@unijos.edu.ng;Tel: +2348036809935
}

\begin{abstract}
The effect of the antioxidant nutrient selenium, Se, on biologic response to cadmium-induced oxidative cytotoxicity was investigated in rats pretreated with Se prior to exposure to mild doses of Cd. Male wistar strain rats (200-250 g b.wt) were exposed to a single daily oral dose of cadmium $(3 \mathrm{mg} \mathrm{CdCl} / \mathrm{kg})$ in drinking water for five days following a 15-day oral supplementation with Se (3.0 or $3.5 \mathrm{mg} \mathrm{SeO} / \mathrm{kg} / \mathrm{day}$ ) in drinking water at the end of which membrane lipid peroxidation, ascorbic acid and glutathione contents and activities of antioxidant enzymes catalase, superoxide dismutase, and glutathione peroxidase were determined in the red blood cell, liver and kidney samples obtained from treated animals. Cadmium content was determined in liver and kidney samples. Results showed that pre-supplementation with Se effectively countered Cd-induced membrane lipid peroxidation, depletion of non-enzymic antioxidants, ascorbic acid, and glutathione, and induction of antioxidant enzymes catalase, superoxide dismutase, and glutathione peroxidase in the RBC, liver and kidney as well as reduced $\mathrm{Cd}$ accumulation in the liver and kidney, all of which effects are consistent with a protective effect of Se against $\mathrm{Cd}$-induced oxidative cytotoxic damage. $\mathrm{RBC}$ was the most susceptible to the inhibitory effect of Se pre-supplementation on Cd-induced lipid peroxidation and tissue ascorbic acid and glutathione depletion.
\end{abstract}

(C) 2012 International Formulae Group. All rights reserved.

Keywords: Cadmium, selenium, lipid peroxidation, antioxidant enzymes, non-enzymes endogenous antioxidants.

\section{INTRODUCTION}

Cadmium, $\mathrm{Cd}$, a toxic heavy metal, is a ubiquitous industrial and environmental pollutant (Gonick, 2008), arising primarily from battery, electroplating, plastics, pigment, fertilizer industries and cigarette smoke. Humans become exposed to $\mathrm{Cd}$ pollutants through the food chain and the air. Following oral exposure, $\mathrm{Cd}$ is absorbed and delivered to the liver by endogenous intestinal protein metallothionein and from the liver it is rapidly redistributed to other organs with the kidney as the main target organ for $\mathrm{Cd}$ toxicity (Asagba, 2009). Public health interest in the toxic effects of environmental $\mathrm{Cd}$ was awakened by epidemiological evidence linking industrial $\mathrm{Cd}$ waste pollution of marine food sources to the outbreak of itai itai disease in Japan, a disease characterized by, among others, severe bone disorders and renal tubular lesions (Tomohito et al., 2010). 
Studies with experimental animals have shown that exposure to $\mathrm{Cd}$ results in toxic lesions in many species, with $\mathrm{Cd}$ showing various mechanisms of toxicity in particular species under different experimental conditions (Waisberg et al., 2003). Severity of $\mathrm{Cd}$ intoxication of target organs is dependent on the route, dose, and duration of exposure and it manifests in various forms ranging from acute toxicosis to cancer. Cadmium causes toxic lesions in target organs by inducing oxidative stress (Patra et al., 2011). It has been demonstrated that $\mathrm{Cd}$ induces oxidative stress by stimulating the production of free radicals such as hydroxyl radicals (Patra et al., 2011), superoxide anions, nitric oxide and hydrogen peroxide (Waisberg et al., 2003), resulting in membrane lipid peroxidation and oxidative deterioration of proteins and DNA and in the process initiating various pathological conditions in humans and animals (Waisberg et al., 2003). Thus, a number of antioxidants and antioxidant defence systems have been shown to protect cells of target organs from Cd toxicity (Swaran, 2009) or to reverse Cd toxicity (Tandon et al., 2003).

Selenium, Se, an antioxidant micronutrient (Hatfield et al., 2009; Toman et al., 2009), that is an essential component of the antioxidant enzyme glutathione peroxidase and of a few other enzymes, has also been reported to exert certain protective effects against $\mathrm{Cd}$ toxicity to such target organs as the liver (Ognjanovic et al., 1995, 2008), the heart and kidneys (Ognjanovic et al., 2008). The reported protective roles include capability of Se to alter the distribution of $\mathrm{Cd}$ in tissues and to induces binding of the $\mathrm{Cd}-\mathrm{Se}$ complexes to proteins which are similar to metallothioneins (Ognjanovic et al., 2008; Toman et al., 2009) and amelioration of $\mathrm{Cd}$-induced oxidative stress and attendant oxidative damage (Ognjanovic et al., 2008). However, these reports on $\mathrm{Se}$ protective action against oxidative stress mediated $\mathrm{Cd}$ toxicity were from studies involving concurrent chronic exposure to $\mathrm{Se}$ and $\mathrm{Cd}$ while other possible forms of exposure appear not to have been appraised. Also the Se protective effect against $\mathrm{Cd}$ oxidative damage appear not to have been reported for the red blood cell, a tissue cell known to be susceptible to $\mathrm{Cd}$ induced oxidative damage (Patra et al, 2011) and for it considerable uptake of $\mathrm{Se}$ (Ognjanovic et al., 2008). Thus, in this study we have examined the effect of presupplementation with $\mathrm{Se}$ on short term exposure to $\mathrm{Cd}$ at a comparatively mild dosean appraisal of a condition where an organism already well nourished with $\mathrm{Se}$ becomes exposed to $\mathrm{Cd}$.

We report on the protective effect of the micronutrient $\mathrm{Se}$ on $\mathrm{Cd}$-induced oxidative lesions as determined by level of the pattern of tissue $\mathrm{Cd}$ bioaccumulation, membrane lipid peroxidation, and activity of the antioxidant defence system in the erythrocyte, hepatic and renal tissues of the rat that had been on Se supplementation.

\section{MATERIALS AND METHODS}

Animal treatment

Wistar Strain male rats (b.wt. 230-250

g) obtained from the Animal House Unit, University of Jos, were used in the study. They were maintained on a standard rat diet, 'Vital Feed' (purchased from Grand Cereals and Oil Mills Ltd, Kuru, Nigeria) and tap water as drinking water, ad libitum. The respective working doses of $\mathrm{Se}\left(\right.$ as $\left.\mathrm{SeO}_{2}\right)$ and $\mathrm{Cd} \quad\left(\mathrm{CdCl}_{2}\right)$ administered orally to experimental animals in this study was first determined in a pilot study. The Cd dose used was the lowest in the graded concentration of the $\mathrm{Cd}$ salt tolerated by the rats with quantifiable tissue biochemical changes without fatality. On the other hand, the Se dose used was the concentration that produced significantly definite positive in the antioxidant defence system capability compared to control rats fed normal diet alone.

Rats were distributed evenly, 4 rats/cages into four standard plastic-metal rat 
cages, labeled A-D, respectively. Rats in the four groups were fed the standard 'Vital feed' rat diet and drinking water ad libitum. However, each rat in groups $\mathrm{C}$ and $\mathrm{D}$ received once daily, an oral supplement of $\mathrm{Se}$ as an aqueous solution of $\mathrm{SeO}_{2}$ administered by means of a needle-free Syringe: each rat in group $\mathrm{C}$ received an oral dose of $3.0 \mathrm{mg}$ $\mathrm{SeO}_{2} / \mathrm{kg}$ b.wt/day while those in group D each received $3.5 \mathrm{mg} \mathrm{SeO} / 2 \mathrm{~kg}$ b.wt/day. The daily oral Se supplementation was carried out for 15 days. Thereafter, rats in group, $\mathrm{B}, \mathrm{C}$ and $\mathrm{D}$ were each given one single oral dose $\mathrm{CdCl}_{2}$ in aqueous solution ( $3 \mathrm{mg} \mathrm{CdCl} / \mathrm{kg}$ b.wt) daily for five days.

\section{Tissue collection and preparation}

At the end of the feeding experiment, on day 21, blood sample was collected from each rat in each group by cardiac puncture under chloroform anaesthesia using heparinized syringe. Each blood sample was transferred into a heparinized centrifuge tube and subsequently centrifuged at 3,000 r.p.m for $10 \mathrm{~min}$ on a MSE centrifuge to obtain red blood cells. The packed RBCs, in each case, were washed twice with ice-cold normal saline and then stored at $2{ }^{\circ} \mathrm{C} / \mathrm{kept}$ on an ice bath pending biochemical analysis which was within a few hours.

After blood collection, rats still under anaesthesia were sacrificed by decapitation and, in each case, the liver and kidneys were excised and washed in ice-cold normal saline to remove adhering blood particles. Homogenates of liver and kidney samples of each rat were prepared separately by homogenizing $1 \mathrm{~g}$ portion in ice-cold $50 \mathrm{mM}$ Tris-HCl buffer, pH7.4 (1:10, w/v) in an Akia homogenizer. The homogenates were centrifuged at $2,400 \mathrm{xg}$ for $10 \mathrm{~min}$ in a refrigerated low-speed centrifuge and the supernatant (S1) fractions were collected with Pasteur Pipette into plastic vials and stored at $2{ }^{\circ} \mathrm{C}$ pending biochemical analysis. The rest of the kidney and liver samples were used for determination of $\mathrm{Cd}$ content.

\section{Biochemical analysis}

Membrane lipid peroxidation, nonenzymic tissue antioxidants (ascorbic acid and glutathione) concentration and antioxidant enzymes (superoxide dismutase, glutathione peroxidase and catalase) activity were determined in the liver and kidney supernatant fractions and red blood cells. Lipid peroxidation was estimated by the thiobarbituric acid reaction method described by Ohkawa et al. (1979). Ascorbic acid content was determined by the method of Roe and Kuether (1943) as modified by Tiez (1970) and glutathione concentration by the Ellman reaction (Ellman, 1959) method as described by Beutler et al. (1963). Catalase activity was assayed by the spectrophotometric method of Aebi et al. (1995); the assay of glutathione peroxidase activity based on the principle of oxidation of GSH to GSSG was by the procedure described by Egbuna (1992). Superoxide dismutase activity was assayed as described by Heikkila and Cabbat (1976).

\section{Tissue cadmium determination}

The cadmium contents of the liver and kidney tissue were estimated with inductively couple plasma optical emission spectrophotometer (ICP OES) optima 2000DV after wet digestion. $1 \mathrm{~g}$ portion of the tissue was digested with $20 \mathrm{ml} \mathrm{HNO}-\mathrm{HCLO}_{4}$ mixture $(1: 4 \mathrm{v} / \mathrm{v})$ at $100{ }^{\circ} \mathrm{C}$ and the resultant digest diluted to $100 \mathrm{ml}$ with deionized water (Asagba et al., 2004).

\section{Statistical analysis}

Statistical analysis of numerical data (expressed as mean $\pm \mathrm{SD}$ ) was done using the statistical package for the social sciences software (SPSS) programme. One way analysis of variance (ANOVA) with post hoc analysis was used to assess the differences between the experimental groups and statistical significance was considered at $\mathrm{p}<0.05$. In addition to ANOVA, the student's t-test was used to compare the various means. 


\section{RESULTS}

\section{Tissue cadmium content}

The results of tissue cadmium determination are summarized on Table 1. As could be seen from the table, cadmium was detected in both the liver and kidney of control rats, suggesting that the experimental rats had previously been exposed to traces of Cd. The table shows that tissue $\mathrm{Cd}$ content was significantly higher in the liver and kidney of rats fed the normal diet alone, prior to exposure to cadmium (group B) than in the corresponding tissues of rats given the normal diet and $3 \mathrm{mg} \mathrm{Se} / \mathrm{kg}$ prior to $\mathrm{Cd}$ exposure (group C). The tissue Cd contents of group B rats were also generally higher than those of rats given the normal diet and $3.5 \mathrm{mg} \mathrm{Se} / \mathrm{kg}$ prior to exposure to $\mathrm{Cd}$ (group D) but the difference was significant only in the case of the kidney. This would suggest that prior supplementation with $\mathrm{Se}$ impaired $\mathrm{Cd}$ bioaccumulation in the liver and kidney in a dose dependent manner, with the lower Se dose being the more potent. The cadmium content of the kidney was generally high than that of the liver.

\section{Membrane lipid peroxidation}

Table 2 summarizes the results of the assay of membrane lipid peroxidation. The tissue concentrations of lipid peroxidation products (determined as malonaldehyde) are significantly higher in the RBC, liver and kidney if rats fed the normal diet prior to $\mathrm{Cd}$ exposure (group B) than in the corresponding tissues of the control rat (group A), suggesting that exposure to $\mathrm{Cd}$ stimulated membrane lipid peroxidation. Tissue concentrations of membrane lipid peroxidation products were also significantly higher in the RBC, liver and kidney of rats in group $B$ than in the corresponding tissues of rats in either of the two groups pre-supplemented with $\mathrm{Se}$, an indication that pre-supplementation with Se protected against Cd-induced lipid peroxidation. However, the level of lipid peroxidation was generally higher in the tissues of rats pre-supplemented with the higher Se dose (group D) than in those that received the lower $\mathrm{Se}$ dose (group $\mathrm{C}$ ), suggesting that the protective effect of $\mathrm{Se}$ against Cd-induced membrance lipid peroxidation was dose-dependent, decreasing with increase in dose.

\section{Non-enzymic tissue antioxidants}

The results of tissue ascorbic acid and glutathione determinations are summarized on Tables 3 and 4, respectively. In each case, the levels of antioxidants were significantly much lower in the RBC, liver, and kidney of rats fed the normal diet prior to exposure to $\mathrm{Cd}$ (group B) than in the corresponding tissue of the control (group A), suggesting that exposure to $\mathrm{Cd}$ markedly depleted ascorbic acid and glutathione stores of the RBC, liver and kidney. Also, in each case, the levels of antioxidant were significantly lower in the $\mathrm{RBC}$, liver and kidney of rats in group $\mathrm{B}$ than in the corresponding tissues of rats fed the normal diet supplemented with the lower Se dose prior to $\mathrm{Cd}$ exposure (group $\mathrm{C}$ ). The difference in tissue antioxidant level between rats in group B and those fed the normal diet supplemented with the higher Se dose prior to Cd exposure (group D) was significant only in the case of the RBC. These would suggest that pre-supplementation with Se had a sparing effect on tissue ascorbic acid and glutathione, inhibiting their depletion by $\mathrm{Cd}$; that the sparing effect is dose dependent with the lower Se being the more potent, and that the RBC was the most sensitive of the three tissue to the tissue antioxidant sparing effect of Se. Tables 3 and 4 also show that ascorbic acid and glutathione contents were highest, per unit tissue weight, in the RBC.

\section{Antioxidant enzymes}

Tables 5, 6 and 7 summarize the results of the assay of activities of tissue antioxidant enzymes catalase, superoxide dismutase and 
glutathione peroxidase, respectively. Catalase activity (Table 5) is significantly higher in the $\mathrm{RBC}$, liver and kidney of rats fed the normal diet prior to Cd exposure (group B) than in the corresponding tissues of the control, (group A), suggesting $\mathrm{Cd}$ induction of antioxidant enzyme activity. Also, catalase activity was significantly higher in the RBC, liver and kidney of rats in group $\mathrm{B}$ than in the corresponding tissues of rats fed the normal diet supplemented with the lower Se dose (group C); the difference in tissue catalase activity between rats in group B and those fed the normal diet supplemented with the higher Se dose (group D) is significant only in the case of the RBC. These would suggest that pre-supplementation with $\mathrm{Se}$ impaired $\mathrm{Cd}$ induction of catalase activity in a dosedependent manner, with the lower dose being the more potent. A similar trend was observed in the superoxide dismutase (SOD) and glutathione peroxidase (GPx) data except that activities of the two antioxidant enzymes were significantly higher in the RBC, liver and kidney of rats in group $\mathrm{B}$ than in the corresponding tissues of rats in the two groups fed the normal diet supplemented with Se prior to $\mathrm{Cd}$ exposure (groups $\mathrm{C}$ and $\mathrm{D}$ ), suggesting that Se effectively antagonized $\mathrm{Cd}$ induction of tissue SOD and GPx activity at the two levels of Se pre-supplementation, although the lower Se dose remains the more potent.

Table 1: Effect of pre-supplementation with selenium on cadmium content of rat liver and kidneys.

\begin{tabular}{|c|c|c|c|}
\hline \multirow[b]{2}{*}{ Group } & \multirow[b]{2}{*}{ Treatment } & \multicolumn{2}{|c|}{ Cadmium concentration ( $\mu \mathrm{g} / \mathrm{g}$ tissue $)$} \\
\hline & & Liver & Kidney \\
\hline A & ND (Control) & $0.30 \pm 0.06$ & $0.43 \pm 0.02$ \\
\hline B & ND15days; then Cd & $3.78 \pm 0.51^{\mathrm{a}}$ & $4.72 \pm 0.72^{\mathrm{a}}$ \\
\hline $\mathrm{C}$ & $\mathrm{ND}+\mathrm{Se}(3 \mathrm{mg} / \mathrm{kg}) 15$ days, then $\mathrm{Cd}$ & $2.39 \pm 0.53^{\mathrm{ab}}$ & $2.83 \pm 0.45^{\mathrm{ab}}$ \\
\hline $\mathrm{D}$ & $\mathrm{ND}+\mathrm{Se}(3.5 \mathrm{mg} / \mathrm{kg}) 15$ days, then $\mathrm{Cd}$ & $3.50 \pm 0.23^{\mathrm{a}}$ & $3.42 \pm 0.21^{\mathrm{ab}}$ \\
\hline
\end{tabular}

Table 2: Effect of pre-supplementation with selenium on cadmium- induced lipid peroxidation in RBC, liver and kidneys.

\begin{tabular}{|c|c|c|c|c|}
\hline \multirow{2}{*}{ Group } & \multirow{2}{*}{ Treatment } & \multicolumn{3}{|c|}{ Malondialdehyde concentration (nmol/g tissue) } \\
\hline & & RBC & Liver & Kidneys \\
\hline A & ND (Control) & $5.41 \pm 0.79$ & $14.95 \pm 0.59$ & $19.66 \pm 0.79$ \\
\hline B & ND 15days, then Cd & $11.73 \pm 1.53^{\mathrm{a}}$ & $40.25 \pm 0.88^{\mathrm{a}}$ & $41.17 \pm 0.59^{\mathrm{a}}$ \\
\hline $\mathrm{C}$ & $\mathrm{ND}+\mathrm{Se}(3 \mathrm{mg} / \mathrm{kg}) 15$ days, $\mathrm{Cd}$ & $6.21 \pm 1.02^{\mathrm{ab}}$ & $28.98 \pm 0.84^{\mathrm{ab}}$ & $25.07 \pm 0.96^{\mathrm{ab}}$ \\
\hline $\mathrm{D}$ & $\mathrm{ND}+\mathrm{Se}(3.5 \mathrm{mg} / \mathrm{kg}) 15$ days, $\mathrm{Cd}$ & $8.33 \pm 1.21^{\mathrm{ab}}$ & $35.77 \pm 1.42^{\mathrm{ab}}$ & $29.67 \pm 2.33^{\mathrm{ab}}$ \\
\hline
\end{tabular}


Table 3: Effect of pre-supplementation with selenium on ascorbic acid levels in the RBC, liver and kidney of rats exposed to $\mathrm{Cd}$.

\begin{tabular}{|c|c|c|c|c|}
\hline \multirow{2}{*}{ Group } & \multirow{2}{*}{ Treatment } & \multicolumn{3}{|c|}{ Ascorbic acid concentration (mg/g tissue) } \\
\hline & & RBC & Liver & Kidneys \\
\hline A & ND (Control) & $1.57 \pm 0.03$ & $1.34 \pm 0.04$ & $1.13 \pm 0.03$ \\
\hline B & ND 15days, then Cd & $0.52 \pm 0.02^{\mathrm{a}}$ & $0.71 \pm 0.04^{\mathrm{a}}$ & $0.53 \pm 0.06^{\mathrm{a}}$ \\
\hline $\mathrm{C}$ & $\mathrm{ND}+\mathrm{Se}(3 \mathrm{mg} / \mathrm{kg}) 15$ days, $\mathrm{Cd}$ & $1.06 \pm 0.02^{\mathrm{ab}}$ & $1.01 \pm 0.11^{\mathrm{ab}}$ & $0.93 \pm 0.06^{\mathrm{ab}}$ \\
\hline $\mathrm{D}$ & $\mathrm{ND}+\mathrm{Se}(3.5 \mathrm{mg} / \mathrm{kg}) 15$ days, $\mathrm{Cd}$ & $0.91 \pm 0.09^{\mathrm{ab}}$ & $0.73 \pm 0.04^{\mathrm{a}}$ & $0.63 \pm 0.03^{\mathrm{a}}$ \\
\hline
\end{tabular}

Table 4: Effect of pre-supplementation with selenium on tissue glutathione content of rats exposed to $\mathrm{Cd}$.

\begin{tabular}{|c|c|c|c|c|}
\hline \multirow[b]{2}{*}{ Group } & \multirow[b]{2}{*}{ Treatment } & \multicolumn{3}{|c|}{ Glutathione concentration $(\mu \mathrm{mol} / \mathrm{g}$ tissue $)$} \\
\hline & & RBC & Liver & Kidneys \\
\hline A & ND (Control) & $0.095 \pm 0.001$ & $0.090 \pm 0.002$ & $0.071 \pm 0.001$ \\
\hline B & ND 15days, then Cd & $0.041 \pm 0.007^{\mathrm{a}}$ & $0.034 \pm 0.002^{\mathrm{a}}$ & $0.028 \pm 0.002^{\mathrm{a}}$ \\
\hline $\mathrm{C}$ & $\mathrm{ND}+\mathrm{Se}(3 \mathrm{mg} / \mathrm{kg}) 15$ days, $\mathrm{Cd}$ & $0.061 \pm 0.009^{\mathrm{ab}}$ & $0.062 \pm 0.002^{\mathrm{ab}}$ & $0.052 \pm 0.004^{\mathrm{ab}}$ \\
\hline $\mathrm{D}$ & $\mathrm{ND}+\mathrm{Se}(3.5 \mathrm{mg} / \mathrm{kg}) 15$ days, $\mathrm{Cd}$ & $0.056 \pm 0.007^{\mathrm{ab}}$ & $0.054 \pm 0.003^{\mathrm{a}}$ & $0.030 \pm 0.002^{\mathrm{a}}$ \\
\hline
\end{tabular}

Table 5: Effect of pre-supplementation with selenium on catalase activity in tissues of rats exposed to $\mathrm{Cd}$.

\begin{tabular}{|c|c|c|c|c|}
\hline \multirow{2}{*}{ Group } & \multirow{2}{*}{ Treatment } & \multicolumn{3}{|c|}{ Catalase activity $(\mu \mathrm{mol} / \mathrm{g}$ tissue $)$} \\
\hline & & RBC & Liver & Kidneys \\
\hline A & $\mathrm{ND}$ (Control) & $6.71 \pm 1.22$ & $5.45 \pm 0.29$ & $4.19 \pm 0.39$ \\
\hline $\mathrm{B}$ & ND 15days, then Cd & $16.57 \pm 1.81^{\mathrm{a}}$ & $14.11 \pm 0.44^{\mathrm{a}}$ & $11.18 \pm 1.02^{\mathrm{a}}$ \\
\hline $\mathrm{C}$ & $\mathrm{ND}+\mathrm{Se}(3 \mathrm{mg} / \mathrm{kg}) 15$ days, $\mathrm{Cd}$ & $8.58 \pm 1.30^{\mathrm{ab}}$ & $9.27 \pm 0.88^{\mathrm{ab}}$ & $9.46 \pm 0.39^{\mathrm{ab}}$ \\
\hline $\mathrm{D}$ & $\mathrm{ND}+\mathrm{Se}(3.5 \mathrm{mg} / \mathrm{kg}) 15$ days, $\mathrm{Cd}$ & $11.51 \pm 1.60^{\mathrm{ab}}$ & $13.47 \pm 3.42^{\mathrm{a}}$ & $11.17 \pm 0.69^{\mathrm{a}}$ \\
\hline
\end{tabular}


Table 6: Effect of pre-supplementation with selenium on superoxide dismutase activity in tissues of rats exposed to $\mathrm{Cd}$.

\begin{tabular}{|c|c|c|c|c|}
\hline \multirow{2}{*}{ Group } & \multirow{2}{*}{ Treatment } & \multicolumn{3}{|c|}{ SOD activity (unit/g tissue) } \\
\hline & & RBC & Liver & Kidneys \\
\hline A & ND (Control) & $2.78 \pm 3.2$ & $20.22 \pm 12.71$ & $6.86 \pm 5.88$ \\
\hline B & ND 15days, then Cd & $97.22 \pm 3.21^{\mathrm{a}}$ & $85.11 \pm 3.47^{\mathrm{a}}$ & $67.54 \pm 2.03^{\mathrm{a}}$ \\
\hline $\mathrm{C}$ & $\mathrm{ND}+\mathrm{Se}(3 \mathrm{mg} / \mathrm{kg}) 15$ days, $\mathrm{Cd}$ & $41.66 \pm 3.2^{\mathrm{ab}}$ & $27.66 \pm 2.45^{\mathrm{ab}}$ & $41.18 \pm 2.63^{\mathrm{ab}}$ \\
\hline $\mathrm{D}$ & $\mathrm{ND}+\mathrm{Se}(3.5 \mathrm{mg} / \mathrm{kg}) 15$ days, $\mathrm{Cd}$ & $66.67 \pm 4.53^{\mathrm{ab}}$ & $43.62 \pm 2.12^{\mathrm{ab}}$ & $65.68 \pm 1.96^{\mathrm{a}}$ \\
\hline \multirow{2}{*}{\multicolumn{5}{|c|}{$\begin{array}{l}\text { Data are expressed as mean } \pm \text { SD, } n=4 \text { for each group. } \\
\text { a values are sionificantly different from control }(\mathrm{n}<0.05)\end{array}$}} \\
\hline & & & & \\
\hline \multicolumn{5}{|c|}{${ }^{\mathrm{b}}$ values are significantly different from the group treated with $\mathrm{Cd}$ alone $(\mathrm{p}<0.05)$} \\
\hline \multicolumn{5}{|c|}{$\mathrm{ND}=$ Normal diet } \\
\hline
\end{tabular}

Table7: Effect of pre-supplementation with selenium on glutathione peroxidase activity in tissues of rats exposed to $\mathrm{Cd}$.

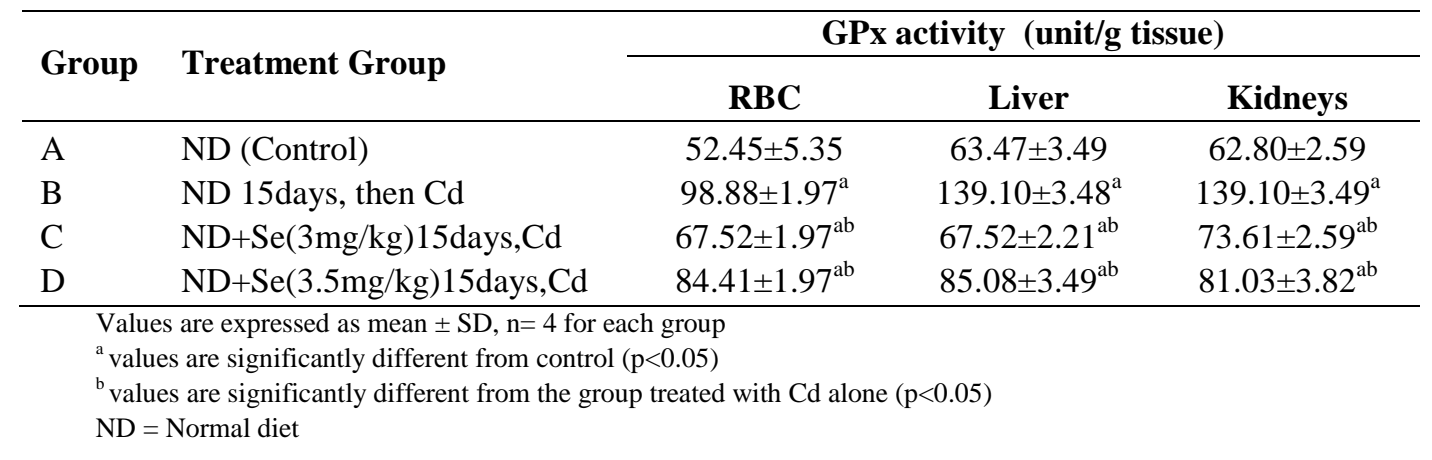

\section{DISCUSSION}

Our study has examined the effect of selenium on the response of the antioxidant defence and cadmium disposition systems to exposure to mild concentrations of cadmium in a situation where the experimental animal has undergone Se supplementation prior to $\mathrm{Cd}$ exposure (that is, the logical opposite of a situation where the experimental animal was made Se deficient prior to $\mathrm{Cd}$ exposure). This approach is at variant with recent reports which appear to focus essentially on the response of these systems in situations where $\mathrm{Cd}$ and $\mathrm{Se}$ were administered concurrently to the experimental animal or where $\mathrm{Cd}$ intoxicated organism is fed Se.

On cadmium disposition, our finding is that prior supplementation with selenium significantly alters the pattern of $\mathrm{Cd}$ disposition, markedly reducing the level of bioaccumulation of $\mathrm{Cd}$ in the rat liver and kidney. This behaviour is consistent with a protective effect of selenium from $\mathrm{Cd}$ toxicity to these target organs. No such significant reduction in $\mathrm{Cd}$ bioaccumulation was observed in a study on rats in which $\mathrm{Cd}$ and Se were given concurrently for a much period and at a much high $\mathrm{Cd}$ dose (Ognjanovic et al., 2008) notwithstanding that the overall data reflected a protective effect for Se.

The absorption of cadmium from the gut lumen is mediated by an endogenons intestinal protein metallothionein (Asagba, 2009) which also facilitates $\mathrm{Cd}$ transport to the liver and presumably the redistribution of the metal ion to the kidney and other organs of 
the body. Cadmium and selenium have very closely related absorption and transport mechanisms and metallothionein is reportedly a key factor in the protective effects of Se from Cd toxicity. Selenium transport proteins are so very closely similar to cadmium binding metallothionein that they can bind both metal ions (Toman et al., 2009) and selenium has been shown to hold the key to the binding of Se-Cd complexes to those of metallothionein-like proteins. It would therefore appear that following presupplementation with Se over a 15 day period prior to $\mathrm{Cd}$ exposure, the mutual transport system may have become primed for Se absorption and transport, thereby reducing the rate of $\mathrm{Cd}$ absorption and bioaccumulation in the rat liver and kidney, a development consistent with a protective role for selenium in cadmium hepatotoxicity and renal toxicity. This would appear to also explain why no reduction in $\mathrm{Cd}$ bioaccumulation in the liver and kidney was observed following concurrent chronic exposure to $\mathrm{Cd}$ and Se.

The generally higher concentration of $\mathrm{Cd}$ in the kidney than in the liver is consistent with its being the major target organ for cadmium toxicity (Asagba, 2009). The presence, albeit in trace quantities, of cadmium in the liver and kidney of rats on the control diet has also been observed by other workers (Asagba et al., 2004; 2006; Ognjanovic et al., 2008). It is a testimony of the ubiquity of cadmium in the food chain and the environment; including the plastic components of the rat cage. The several fold lower tissue concentrations of Cd observed in this study in rats exposed to Cd compared to those reported by other workers (Asagba et al., 2004; 2006; Ognjanovic et al., 2008) are a reflection of the relatively mild dose and short duration of $\mathrm{Cd}$ exposure. These workers exposed rats to $\mathrm{Cd}$ at the levels of $100 \mathrm{mg}$ $\mathrm{Cd} / \mathrm{kg}$ for 16 weeks (Asagba et al., 2004; 2006) and $15 \mathrm{mg} \mathrm{Cd} / \mathrm{kg}$ for 4 weeks (Ognjanovic et al., 2008), respectively compared to our $3 \mathrm{mg} / \mathrm{Cd} / \mathrm{kg}$ for 5 days.
Membrane lipid peroxidation is a major early manifestation of oxidative damage to the liver and kidney tissues by cadmium (Swaran, 2009) and it plays on important role in the induction of toxic lesions by many prooxidant foreign metal ions like $\mathrm{Cd}$ (Waisberg et al., 2003). Our findings confirm that exposure to cadmium causes a significant increase in membrane lipid peroxidation in the liver, kidney and in the red blood cells. Our finding that prior supplementation with $\mathrm{Se}$ significantly reduced the level of Cd-induced membrane lipid peroxidation in the three tissues is consistent with a protective effect of Se from Cd toxicity to the rat and is in accord with reported protective effects of antioxidant nutrients against $\mathrm{Cd}$-induced oxidative stress and lipid peroxidation in the liver and kidney (Deepti et al., 2010). A similar reduction in the level of Cd-induced lipid peroxidation in the liver and kidney has been reported in rats fed $\mathrm{Se}$ and $\mathrm{Cd}$ concurrently. The extent of reduction of $\mathrm{Cd}$-induced lipid peroxidation by Se pre-supplementation (3 $\mathrm{mg} \mathrm{Se} / \mathrm{kg}$ ) was highest in the RBC (47.06\%)followed by the kidney $(39.11 \%)$ and liver $(28.0 \%)$ suggesting that Se mitigation of cadmium-induced lipid peroxidation is most effective in the RBC.

The protective role of endogenous non-enzymic antioxidants against oxidative damage by free oxy-radicals and the depletion of their tissue reserves in the process have long been documented (Swaran, 2009). They are used up in the course of destroying the oxy-radicals. Our study found that exposure to cadmium induced a significant depletion of ascorbic acid and glutathione in the rat RBC, liver and kidney, a lesion which was effectively prevented by pre-supplementation with Se. Depletion of tissue reserves of endogenous antioxidants, ascorbic acid and glutathione, on exposure to $\mathrm{Cd}$ is the expected biologic response since cadmium is known to induce oxidative stress through generation of oxy- radicals (Swaran, 2009). That exposure to cadmium induces depletion of ascorbic acid in the blood, liver and kidney is well documented (Patra et al., 2011). The observed 
sparing effect of Se pre-supplementation on Cd-induced depletion of both antioxidants in the rat RBC, liver and kidney is consistent with a protective role for $\mathrm{Se}$ in $\mathrm{Cd}$ toxicity. The extent of the sparing of endogenous antioxidants from $\mathrm{Cd}$ induced depletion by selenium supplementation (3 $\mathrm{mg} \mathrm{Se} / \mathrm{kg}$ ) was highest in the RBC (103.85\%) followed by the kidney $(43.01 \%)$ and liver $(42.25 \%)$ in the case of ascorbic acid, but the reverse was the case with glutathione the kidney $(85.71 \%)$, liver $(82.35 \%)$ and RBC $(48.78 \%)$. This would appear to suggest that sparing effect of Se pre-supplementation or tissue ascorbic acid and glutathione was most effective in the RBC and kidney, respectively. The underlying mechanism of this tissue difference in Se action is not readily understood. No significant sparing effect was observed in the hepatic and renal ascorbic acid content of rats given Se and Cd concurrently (Ognjanovic et al., 2008) - the ascorbic acid depleting effect was more pronounced than the sparing effect of Se. As with Cd-induced depletion, there appears to be no report on the effect of $\mathrm{Se}$ on $\mathrm{Cd}$-induced glutathione depletion in the three tissues.

Catalase, superoxide dismutase (SOD), and glutathione peroxidase are the three primary antioxidant enzymes of the endogenous defence systems for the removal of reactive oxygen species (Patra et al., 2011), being the first enzymatic antioxidant defences for the body against oxidant-induced cytotoxic challenge. Upon ingestion, many xenobiotics, including proxidants, such as 2, 4dinitrophenyl hydrazine (Maduka and Okoye, 2002), induce the enzymes that metabolize them. 2, 4-Dinitrophenyl hydrazine causes lipid peroxidation in the body through the formation of superxide anions. Our results have shown that in all three cases, exposure to cadmium significantly induced enzyme activity which was effectively reversed by pre-treatment with selenium. However, these findings are at variance with results obtained from studies on long-term exposure to relatively high doses of cadmium which observed Cd inhibition of SOD in the rat liver and kidney (Asagba et al., 2004; Ognjavic et al., 2008) and RBC and of rat liver and kidney glutathione peroxidase and liver catalase (Ognjanovic et al., 2008). The inhibitory action of $\mathrm{Cd}$ on the three antioxidant enzymes was reportedly effectively reversed on concurrent exposure to both $\mathrm{Cd}$ and $\mathrm{Se}$ (Ognjanovic et al., 2008). The apparent contradiction between these reports and our present findings is traceable to the difference in the oral dose of $\mathrm{Cd}$ and duration of exposure. As discussed earlier, our cadmium dose $(3 \mathrm{mg} / \mathrm{kg})$ is relatively mild compared to the working Cd dose of between $15 \mathrm{mg} \mathrm{Cd} / \mathrm{kg}$ (Ognjanovic et al., 2008) and $100 \mathrm{mg} \mathrm{Cd} / \mathrm{kg}$ (Asagba et al., 2004) employed by these other workers for durations ranging from four weeks (Ognjanovic et al., 2008) to 16 weeks (Asagba et al., 2004) to the five-day $\mathrm{Cd}$ exposure in our study. These differences are reflected in the tissue load of cadmium: the mean liver and kidney $\mathrm{Cd}$ content of $3.78 \pm$ 0.51 and $4.72 \pm 0.72 \mathrm{mg} \mathrm{Cd} / \mathrm{g}$ tissue respectively, obtained in our study are extremely mild compared to the corresponding values of $21.26 \pm 1.72$ and $23.4 \pm 1.68 \mathrm{mg} / \mathrm{g}$ tissue (Ognjanovic et al., 2008) and $50.50 \pm 1.43$ and $75.30 \pm 0.94 \mathrm{mg}$ $\mathrm{Cd} / \mathrm{g}$ tissue (Asagba et al., 2004) reported by other workers. At such high tissue concentrations, $\mathrm{Cd}$ is believed to exert direct toxic effects on the antioxidant enzymes (Ognjanovic et al., 2008), including inhibition of enzyme activity through displacement of divalent cations from the enzyme active site of the respective antioxidant enzymes; which are metalloenzymes.

One common trend observed in the results discussed above was the dose dependence of Se influence on Cd action on the rat tissue. The extent of Se moderation of $\mathrm{Cd}$ action was such that while the influence of the lower dose of selenium ( $3 \mathrm{mg} \mathrm{Se} / \mathrm{kg}$ ) on Cd-induced lesions invariably significantly affected all the three tissues, RBC, liver and kidney, that of the higher dose $(3.5 \mathrm{mg} \mathrm{Se} / \mathrm{kg})$ with the exception of lipid peroxidation and 
SOD and glutathione peroxidase, significantly affects only one or two tissues: impairment of $\mathrm{Cd}$ accumulation only in the liver; sparing effect on ascorbic acid and glutathione only in the RBC and induction of catalase only in the liver. These would suggest that the dose used in this study may be in the upper segment of the three hold of Se dose that influence $\mathrm{Cd}$ action. Ognjanovic and coworkers (2008) administered Se at a much lower dose $(0.5 \mathrm{mg}$ $\mathrm{Se} / \mathrm{kg}$ ) that was employed in this study.

\section{Conclusion}

It can be concluded from the findings of our investigations as discussed above that Se sufficiency offers protection against $\mathrm{Cd}$ challenge in particular, that an organism well nourished with respect to selenium at the time of $\mathrm{Cd}$ exposure has a more effective defence capability against Cd-induced oxidative damage to tissue than otherwise as determined by the various parameters. The extent of influence of prior supplementation with Se on the $\mathrm{Cd}$ disposition system, membrane lipid peroxidation and the antioxidant defence system are consistent with a protective influence of Se on Cd induced oxidative stress and cytotoxicity.

\section{REFERENCES}

Aebi U, Chiu W, Milligan R. 1995. Role of catalase on antioxidative defences. $J$ Struct. Biol., 2: 117-118.

Asagba SO, Eriyamremu GE, Adaikpoh MA, Ezeoma A. 2004. Levels of lipid peroxidation, superoxide dismutase and $\mathrm{Na}+\mathrm{K}+-\mathrm{ATPase}$ in some tissues of rats exposed to a Nigerian diet and cadmium. Biol. Trace Elem. Res., 100(1): 075-086.

Asagba SO, Eriyamremu GE, Onyeneke EC, Suru M. 2006. Influence of a Nigerianlike diet on calcium, phosphate and alkaline phosphatase levels in the plasma and bone of cadmium exposed rats. $J$. Med. Sci., 6(5): 758-764.

Asagba SO, Eriyamremu GE. 2007. Oral cadmium exposure and levels of superoxide dismutase, catalase, lipid peroxidation and ATPases in the eye. Res. J. Environ. Toxicol., 1(4): 204-209.

Asagba SO. 2009. Role of diet in absorption and toxicity of oral cadmium-A review of literature. Afr. J. Biotechnol., 8(25): 7428-7436.

Baldisserotto B, Chowdhury MJ, Wood CA. 2005. Effects of dietary calcium and cadmium on cadmium accumulation, calcium and cadmium uptake from the water, and their interactions in juvenile rainbow trout. Aquatic Toxicology, 72: 99-117.

Baldisserotto B, Chowdhury MJ, Wood CM. 2006. In vitro analysis of intestinal absorption of cadmium and calcium in rainbow trout fed with calcium- and cadmium-supplemented diets. Journal of Fish Biology, 69: 658-667.

Deepti G, Shabad P, Dua KK. 2009. Chronic cadmium toxicity in rats: treatment with combined administration of vitamins, amino acids, antioxidants and essential Metals. Journal of Food and Drug Analysis, 18(6): 464-470.

Egbuna CN. 1992. A biochemical assessment of the neurotoxicity of Nigerian local gin and its remission by vitamins $\mathrm{B} 1$ and $\mathrm{E}$, A Ph.D Thesis, University of Benin, Nigeria.

Ellman GL. 1959. Tissue sulfhydryl groups. Arch. Biochem. Biophys., 82(1): 70-77.

Gonick HC. 2008. Nephrotoxicity of cadmium and lead. Indian J. Med. Res., 1283: 3552.

Heikkila RE, Cabbat F. 1976. A sensitive assay for superoxide dismutase based on the autoxidation of 6-hydroxydopamine. Analytical Biochemistry, 75: 356-362.

Ishido M, Ohtsubo R, Adachi T, Kunimoto M. 2002. Attenuation of both apoptotic and necrotic actions of cadmium by Bcl-2. Environ. Health Perspect., 110: 37-42.

Maduka HCC, Okoye ZSC. 2002. The effect of sacoglottis gabonensis stem bark extract, a Nigeria alcoholic beverage additive, on the natural antioxidant defences during 2,4-dinitrophenyl- 
hydrazine-induced membrane peroxidation in vivo. Vascular pharmacology, 39: 21-31.

Ohkawa H, Ohishi N, yagi K. 1979. Assay for lipid peroxides in animal tissues by thiobarbituric acid reaction. Anal Biochem., 95: 351-358.

Ognjanovic B, Zikic RV, Stajn A, Saicic ZS, Kostic MM, Petrovic VM. 1995. The effects of selenium on the antioxidant defense system in the liver of rats exposed to cadmium. Physiol. Res., 44: 293-300.

Ognjanovic BI, Markovic SD, Pavlovic SZ, Zikic RV, Stajn AS, Saicic ZS. 2008. Effect of chronic cadmium exposure on antioxidant defense system in some tissues of rats: protective effect of selenium. Physiol. Res., 57: 403-411.

Patra RC, Amiya KR, Swarup D. 2011. Oxidative stress in lead and cadmium toxicity and its amelioration. Vet. Med. Int., 2011: Article ID 457327, 9 pages, doi:10.4061/2011/457327.

Patra RC, Swarup D, Senapati SK. 1999. Effects of cadmium on lipid peroxides and superoxide dismutase in hepatic, renal and testicular tissue of rats. Vet. Hum. Toxicol., 41: 65-67.

Roe JH, Kuether CA. 1943. Estimation of ascorbic acid. Journal of Biological Chemistry, 147: 399-423.
Swaran JSF. 2009. Structural, chemical and biological aspects of antioxidants for strategies against metal and metalloid exposure. Oxidative Medicine and Cellular Longevity, 2(4): 191-206.

Tandon SK, Singh S, Prasad S, Khandekar K, Dwivedi VK, Chatterjee M, Mathur N. 2003. Reversal of cadmium induced oxidative stress by chelating agent, antioxidant or their combination in rat. Toxicol. Lett., 145: 211-217.

Tietz W. 1970. Fundamentals of Clinical Chemistry. Published by WB Saunders Co: West Washington S.G Philadelphia Pa 19105, USA; 173-176.

Toman R, Golian J, Siska B, Massanyi P, Lukac N, Adamkovicova M. 2009. Cadmium and selenium in animal tissues and their interactions after an experimental administration to rats. Slovak J. Anim. Sci., 42(1): 115-118.

Tomohito A, Akira K, Koji B, Shinsuke M, Shingo M. 2010. Effects of water management on $\mathrm{Cd}$ and As content in rice grain. 19th World Congress of Soil Science, Soil Solutions for a Changing World. Brisbane, Australia, 103-106.

Waisberg M, Joseph P, Hale B, Beyersmann D. 2003. Molecular and cellular mechanisms of cadmium carcinogenesis: a review. Toxicology, 192: 95117. 